This is an Author's Accepted Manuscript of an article published in Research Papers in Education, 27(2), 167-186, 2012, copyright Taylor \& Francis, available online at:

http://www.tandfonline.com/10.1080/02671522.2010.509514

\title{
The Landscape of Gifted and Talented Education in England and Wales: How are teachers implementing policy?
}

\author{
Valsa Koshy, Catrin Pinheiro-Torres and Carole Portman-Smith \\ Brunel University, UK
}

\author{
Corresponding Author: \\ Professor Valsa Koshy \\ Brunel University \\ Cleveland Rd \\ Uxbridge \\ Middlesex \\ UB8 3PH \\ United Kingdom
}




\section{Abstract}

This paper explores the evidence relating to how primary schools are responding to the 'Gifted and Talented' initiative in England and Wales. A questionnaire survey which invited both closed and open-ended responses was carried out with a national sample of primary schools. The survey indicated an increasing proportion of co-ordinators, compared with a survey carried out in 1996, were identifying their gifted and talented children as well as having associated school policies. However, the survey also highlighted a number of issues which need addressing if the initiative is to achieve its objective of providing the best possible educational opportunities for children. For example, it was found that a significant number of practitioners were not aware of the existence of the National Quality Standards for gifted and talented education, provided by the UK government in 2007 and, the subject- specific criteria provided by the UK's Curriculum Authority for identification and provision have been largely ignored. The process of identifying children to be placed on the 'gifted and talented' register seems haphazard and based on pragmatic reasons. Analysis of teachers' responses also revealed a range of views and theoretical positioning held by them, which have implications for classroom practice. As the 'Gifted and Talented' initiative in the UK is entering a second decade, and yet more significant changes in policy are introduced, pertinent questions need to be raised and given consideration.

\section{Background}

In the past few decades there have been many attempts in the UK, by various voluntary agencies, to highlight the lack of provision for higher ability pupils. Her Majesty's Inspectors (HMI 1978; 1979) reported their concern that work was not appropriately matched for able pupils. Many years later, Her Majesty's Inspectorate voiced their view (HMI 1992) that very able pupils in state maintained primary and secondary schools had not been sufficiently challenged by the work they had been set and, more recently, Ofsted (Office for Standards in Education) inspections highlighted that provision for able pupils in state-funded schools was far from satisfactory (Eyre 2001). Low expectations of pupils and teachers' own lack of awareness of how to identify and teach higher ability children were also causes for concern. The first recorded government commitment to making effective provision for high ability pupils can be found in the government White Paper (DfEE 1997) 
and shortly afterwards Estelle Morris (1998), the schools minister, expressed the government's objectives clearly:

The government is committed to improving educational standards for all children.... we fail to identify many of our most able children and we don't challenge them enough. We owe it to these children to help them realize their potential. That means working with schools, parents and local authorities to establish practice. We must celebrate the abilities of our most able children and encourage them to achieve at the highest level. The attitude that gifted children can cope with themselves has let down too many young people.

(DfEE Circular 413/98)

An action plan and very generous funding were provided for developing strategies for meeting the needs of gifted children within the Excellence in Cities initiative (DfEE 1999). The British government invested significantly in the development of the 'gifted and talented' strand within the education policy. As outlined by the team leader for gifted and talented education at the Department of Education and Skills (Dracup 2003), in one financial year 2002-2003 alone, the government provided $£ 70$ million for mostly localised initiatives supporting gifted and talented children from over 80 out of the total 150 Local Education Authorities. Since 1999, the Gifted and Talented policy has been extended to all primary and secondary schools in all Local Authorities in England and Wales. 'Gifted and Talented' co-ordinators were appointed at both Local Authority and school levels to take responsibility for implementing the requirements of the policy. Oxford Brookes University was commissioned to provide training for all school co-ordinators. Later, in order to address the complex requirements of the policy, with no previous established framework available, a National Academy for Gifted and Talented Youth (NAGTY) was set up, using public funds which was to provide support for the top $5 \%$ of the children, although 4 years later it was decided to transfer the responsibility of national co-ordination of the programme to CfBT (Centre for British Teachers) from 2007. Support for the top 10\% of pupils aged 4 to 19 was to be offered. As the research reported in this paper was taking place, it was announced in the national educational newspaper that 'gifted and talented face further reform - yet again' (Maddern 2009) and the article expressed concern that provision for the 'gifted and talented could be sidelined'. A number of changes relating to provision within the gifted and policy have been announced in 2010 . These are discussed later in this section. 
So, to recap, the 'Gifted and Talented' policy, which was initially designed to target underachievement of bright students in the inner-city areas, has since been extended to a programme covering the full age range 4-19. Teachers are expected to identify a gifted and talented population, consisting of 5 to $10 \%$ of the top ability pupils within their schools, and introduce a distinct and discernibly different teaching and learning programme to address the needs of the selected groups of children. Schools are expected to draw up policies which outline how systems are designed to operate and how to set targets for these pupils with the aim of enhancing the quality of teaching of these children. Schools are expected to use 'direct teaching' models which are effective in teaching the gifted and talented. These models are to include 'enquiry, inductive learning and teaching through analogy' (DCSF 2008a). Additionally, these models require learners to collaborate and learn together and help them to construct new knowledge and understand concepts and to include 'constructivism and problem-solving'.

In 2007, the government's National Strategies team was entrusted with the responsibility of providing national training for all teachers in both primary and secondary schools to help them develop effective strategies for making appropriate provision for Gifted and Talented students. A set of guidelines, 'Institutional Quality Standards' (IQS), was circulated to all schools in England and Wales, which was designed to provide a tool for evaluating the effectiveness of what is offered to Gifted and Talented students (DCSF 2008a). The requirement of schools to identify a percentage of their children as 'gifted and talented' and make appropriate provision for them remains central to the policy initiative. Support for teachers is organised through Local Education Authorities and through the appointment of leading teachers either within each school or in a cluster of schools. It is against this background that we set up the project which is reported in this paper.

It should be noted that during the final stages of writing this paper some radical changes have been announced. The National Strategy team, which is responsible for training teachers and providing support with professional development materials, is to be disbanded from March 2011. The 'Gifted and Talented' policy coordinating team within the government department is no longer in place. A government select committee conducted discussions with key players within gifted and talented education and raised concerns (House of Commons 2010). The experts described the national gifted and talented 
programme as 'inconsistent and incoherent' and stated that the impact in classrooms generally with regard to provision was patchy' (G\&T Update, 2010)

\section{Purpose of the project}

The purpose of the research project reported in this paper was to find out how primary schools were implementing the 'Gifted and Talented' education policy and how they were meeting its requirements. We were also interested in exploring the beliefs and theoretical positions of teachers as, ultimately, the quality of education provided for higher ability children will depend on how teachers interpret the policy, their beliefs, understanding of issues and the support and the level of guidance they receive from various sources. Therefore, in this paper, we present analysis and reflections relating to a survey designed to gauge the impact of the 'gifted and talented' policy on teachers and the ultimate beneficiaries of any education policy - the children who are perceived to be 'gifted and talented'. Inherent in that analysis and reflections are fundamental assumptions of the researchers. The primary assumption - without delving into the underlying support which could be generated by hermeneutics - is that teachers' interpretation of documents declaring the objectives of policy guidelines relating to curriculum strategies and identification is strongly influenced by their previously acquired knowledge, training and outlook. It is also a fundamental contention that an analysis of education policy in terms of its inherent logic and perceived goals is an arid exercise unless that analysis considers the interlinking features between policy formulation, policy interpretation and policy implementation.

\section{Teachers and Gifted and Talented education}

Gifted and Talented education in the UK is a relatively new initiative and there has been a relative shortage of published academic papers based on systematic research carried out on how the initiative has been received and implemented by teachers in schools since 2000. Useful research papers on aspects of gifted education include Freeman's review of international research on gifted education (1998) and her subsequent illuminating publications (Freeman, 2001; 2005). Occasional papers were available from the National 
Academy for Gifted and Talented Youth which include Neelands, et al (2006) and Robinson, Campbell and Mazzoli, (2006). Hartas et al's (2009) paper addresses the needs of gifted and talented students with specific focus on mathematics and science from a professional development angle. Research on practical aspects of provision for the gifted and talented, published by Oxford Brookes University (Westminster Institute of Education, 2010), and the systematic review of research on 'what works' in educating gifted and talented students carried out by the EPPI-centre (Bailey et al, 2008) are other publications which address the practitioners' needs.

Research conducted prior to the introduction of the government initiatives had shown that teachers in England and Wales were hostile towards the idea of a policy focusing specifically on gifted children and, as a result, very few schools had differentiated classroom provision for them (Thomas, Casey and Koshy, 1996). Research conducted in other countries indicates that teachers' views of high achieving pupils can have a significant influence on both the identification process and classroom provision for them (Geake and Gross 2008). One such example is a national survey of US primary teachers' conceptions of giftedness which showed that, 'teachers believe that some degree of wealth is a necessary condition in order for academic giftedness to be manifest and recognized' (Moon and Brighton 2008, 474). The set of guidelines provided by the UK government offers teachers ownership of provision and opens the door for them to exercise flexibility and creativity. That said, it is an option not without dangers. In the extreme case guidance may be ignored. More commonly, it will be interpreted in the light of teachers' particular beliefs about teaching, learning and giftedness derived from their training, experience and their taken-for-granted assumptions regarding these matters. The quality of training and opportunities to discuss the complexities of the concept of giftedness can also influence their practices (Koshy and Casey 1997). In conducting this study, we were interested in exploring how schools were implementing government policy and the theoretical positioning of teachers towards giftedness which may be reflected in their actions.

The ultimate purpose of government policy is to enhance the quality of educational provision for gifted and talented children in the classroom. There are challenges for the teacher who has the responsibility for provision for gifted learners in the regular classroom which are highlighted by Van Tassel-Baska (2005b), who has led curriculum development 
for the gifted in the US in the past three decades. The challenges include the influence of teachers' attitudes and beliefs about learning on their teaching, lack of expertise in modifying the curriculum, philosophical barriers and antipathy of many teachers towards the gifted learner and their needs. A study of teachers' views and practices, therefore, is felt to be an important step towards assessing the effectiveness of the implementation of government policy.

\section{Conceptions of ability and theoretical framework}

Although finding the best ways of educating the most able students is considered important and is of interest and concern to all educationists internationally, there is no agreed definition of what giftedness means or how we can identify gifted children. There are various conceptions of 'giftedness' and 'talent' involving contrasting theoretical positions, ranging from the notion that a percentage of a population can be identified to form the membership of a group of 'gifted and talented' individuals who should then be provided with specific programmes, to those who believe that we should focus on maximising opportunities for developing gifts and talents in all children, by moving away from labelling a sub-group as 'gifted'.

For the research reported in this paper we considered four main perspectives on the education of gifted and talented pupils. First, there is the view that giftedness is a 'superfluous or outdated concept and that giftedness is a social invention that serves divisions in society that have no constructive purpose', held by Borland (2005). After many years of involvement in gifted education in the USA, Borland recommends that we should do away with the concept of 'gifted children' and have 'gifted education' in which the techniques that have been developed could be used for all education; this would be advantageous to all children. Borland's proposition that we move away from labelling children to making appropriate intellectual challenges for all learners makes him the vanguard of the paradigm shift toward giftedness as 'doing' rather than 'being'. These views echo that of Claxton and Meadows (2009: 9) who adopt a standpoint that in education our job is to help children develop the 'zeal and hard work' that will enable them to emerge as gifted and talented in their own unique ways. Commenting on the gifted and talented policy perspective in the UK, Claxton and Meadows argue that 'in ten years time the antiquated and dysfunctional idea that 'giftedness' is an 'innate', 'abiding' and 'situation - independent' quality of a fortunate minority of young people would have been removed 
from the discourse of educational practice and policy'. Robinson and Campbell (2010) highlight the ideological debates relating to making special provision for gifted and talented students which was viewed as 'elitist' in academic discourses. They also found that teachers were opposed to the view that giftedness was limited to a fixed proportion of students destined to be the future leaders of the country. In this respect, Robinson and Campbell maintain that the views of the teachers in England were in agreement with the critiques of Borland in the USA and White (2006) in the UK, that the view of a fixed and measurable intelligence, restricted to a small proportion of the population, owes more to theories of eugenics and puritanical pre-destination than it does to educational theory.

The second view involves teachers identifying gifted students using traditional tests - to assess what Renzulli (2005) describes as school house giftedness. In the USA, an identification system based on tests such as SAT is used for selecting students for gifted programmes (Brody and Stanley 2005) and this practice is also used in many other countries such as Singapore and Hong Kong. Brody and Stanley do stress that although this view, which has its origins in the work of Terman (1925) and colleagues who placed the emphasis on the role of IQ (general intelligence), has diminished there are many educators who still equate giftedness with high general ability. In the UK, children take national tests provided by the government through the Qualifications and Curriculum Authority (QCA). Although criterion-referenced tests are used to monitor children's achievement they are not viewed as tests for intelligence.

A third view is held by those who consider the identification of giftedness using tests and IQ-based assessments as too narrow and have proposed more liberal views. Renzulli (2005), for example, with his 'Three-Ring model' emphasises other indicators such as creativity, task-commitment and motivation as equally important as the level of ability. Gardner $(1983,1993)$ put forward his theory of Multiple Intelligences and he, like Van Tassel-Baska, (2005a) holds the view that giftedness is multi-dimensional and rather than relying on a single dimensional measure of ability, we should acknowledge that people possess several forms of specific intelligences which can exist in isolation or in clusters. Sternberg (2000) views giftedness not as a fixed state, but as developing expertise and modifiable and suggests a model (Sternberg 2005) in which Wisdom, Intelligence and Creativity (the WICS model in Sternberg 2009) interact as giftedness develops. He emphasises the role of problem solving, willingness to take risks and tolerate ambiguity, as 
well as the need for the acceptance of the existence of academic and practical intelligence in people. Sternberg proposes that his model may be used for both identifying giftedness and encouraging its development.

Finally, we consider the view of giftedness as an innate endowment or natural gift which is associated with genetic inheritance. This view has been challenged by psychologists (Howe 1999; Ericsson 1996). They believe that all children are born more or less equal, regarding the specific abilities associated with any given domain of achievement and, over time, children become differentiated according to the amount of domain-specific expertise they acquire. The amount of practice - the more time the person has spent mastering domain specific knowledge and skills - the closer he or she will get to attaining world-class performance. The amount of hard work an individual puts in is described as 'drudgery theory' by Simonton (2001).The expertise theorists also attribute the child prodigies' achievements to deliberate practice; for example, Mozart began deliberate practice from a young age owing to the insistence of his musical father and his masterpieces only appeared many years later, after extensive experience (Simonton, 2001).

\section{Research questions}

Our two main research questions were:

1. What do school co-ordinators think of the Gifted and Talented initiative and how are they implementing it in schools?

2. What insights can be gained about school co-ordinators beliefs and possible theoretical positioning?

Additionally, we were interested in following up the research conducted by Thomas, Casey and Koshy (1996) in the UK, and assess whether there has been a shift in school coordinators' beliefs and practices in educating gifted students. 


\section{Methodology and Data}

Data were obtained through an extensive postal questionnaire to a $20 \%$ random, stratified sample of all the primary schools across England and Wales. This sample was recruited by the National Foundation for Education Research (NFER) which is an independent institution. The questionnaires were completed by the gifted and talented co-ordinators, or lead teachers who had responsibility for gifted and talented education in the school. This way it was possible to collect information from the point of view of how both the schools and the teachers were responding to policy. The questionnaire contained both open and closed questions, and was broken down into 4 main areas:

1. Basic information about the school and teacher completing the questionnaire (including details of any training).

2. The schools' current approach to the Gifted and Talented initiative in terms of policy, practice and provision.

3. The thoughts about the guidance provided by the government (Institutional Quality Standards).

4. The teachers' thoughts about the concepts of 'gifts' and 'talents'.

284 school co-ordinators (one per school) responded to the questionnaire which constitutes a $10 \%$ return. We can report that the returned completed questionnaires were demographically representative of the national sample. This level of return is consistent or higher than the number of responses to other recent national surveys with teachers exploring new government initiatives (Sebba et al 2007, for example) in the UK; some explanations for the low return may be useful here. Declared reasons for non-returns from schools included 'pressure of work', 'we don't have time to be involved in academic research' and ' we don't want to respond, unless it is statutory to do so'. We can only speculate on other reasons for the non-return, which could include a reluctance to reveal what is happening in their school, a lack of interest or commitment to 'gifted and talented' education or a possible feeling of inadequacy to deal with the content of the questionnaire. It may also be due to the hostility felt by teachers toward the whole concept of selection and perceived 'elitism' mentioned earlier (Robinson and Campbell, 2010). It is acknowledged that more returns may have influenced the data and the findings - either more positively or negatively. The findings, therefore, are to be considered as a tentative analysis of the schools' engagement with gifted and talented education. Further, it is to be 
borne in mind that the results presented in this paper are based on a first stage analysis of the numerical responses and all the open-ended responses which have been transcribed and coded using thematic analysis. Basic descriptive statistics have been produced based on the closed questions. Only some of the most relevant findings and themes are included in this paper.

\section{Findings and discussion}

Based on the analysis of the responses from school co-ordinators our interpretations, some significant themes are presented and discussed in this paper. We are able to provide some useful insights into how the teachers are implementing the gifted and talented policy in England and Wales. Efforts are also made to discuss the themes in relation to available literature and theoretical perspectives.

\section{Practitioners' engagement with gifted and talented education}

Compared to the findings of our previous national survey of primary schools, (Thomas, Casey and Koshy 1996), there has been a significant shift in the way teachers are responding to the initiative. For example, $96 \%$ of the schools which responded to the present survey identify and record their gifted and talented students and $90 \%$ have a school policy for 'Gifted and Talented' education, compared to only $32 \%$ of schools keeping records of their 'able' children in 1996 or having a policy for teaching gifted and talented children. $67 \%$ responded that they had access to a school-based leader to consult on gifted and talented issues and $84 \%$ had attended some training in aspects of gifted and talented education compared to less than $15 \%$ of schools having a schoolbased on co-ordinator and $20 \%$ having attended one day conferences on gifted education in 1996. However, it was surprising that $34 \%$ of the co-ordinators in the present sample of schools had not heard of the government guidance for schools - 'Institutional Quality Standards' (IQS) which were distributed to schools in 2007 - or felt they had insufficient knowledge to comment on it. It is stressed that we did not ask any questions relating to the CQS (Classroom Quality Standards) as part of this study. This is significant in that the guidance in the IQS is designed for schools to follow and inform teachers on how to plan 
provision and evaluate the effectiveness of what is on offer. A number of co-ordinators commented that the IQS document made things overly complicated.

Based on the responses, it can be stated that schools are responding to policy requirements with a higher degree of commitment and perseverance since the introduction of the gifted and talented policy. However, the reasons for the relative lack of engagement with policy guidelines provided to schools can only be speculated; it may be due to a lack of interest or a perceived inability to make sense of the content of the document. Although it was not part of the present study, it is worth noting that in 2009, when the first author of this paper asked 4 different audiences (keynote address delivered to over 120 participating teachers, each time) in different geographical areas of England, no more than 10 people in each group were aware of the existence of the Institutional Quality standards.

\section{Selection of the gifted and talented cohorts}

\section{Difficulties with terminology}

Practitioners' attitude to the use of the terminology of 'Gifted and Talented' had not changed much since our 1996 survey (Thomas, Casey and Koshy 1996) when 86\% of teachers felt uncomfortable about labelling children as 'gifted and talented'. The present study showed that there was unease felt by $62 \%$ of teachers about labelling children as 'gifted' and that they preferred the use of 'more able' to describe these pupils. One other problematic area for teachers seems to be the separation of 'Gifted' and 'Talented' students. The UK government definition of the phrase 'Gifted and Talented' (DfES 2006) clustering the two terms - 'gifted' and 'talented' - together with the explanation: 'Gifted describes learners who have the ability to excel academically in one or more subjects such as English, drama, technology. Talented describes learners who have the ability to excel in practical skills such as sport, leadership, artistic performance, or in an applied skill' seems to have confused practitioners. $78 \%$ of schools did not have separate registers for 'Gifted' and 'Talented' students. This raises several questions about how students are identified and placed on the register. One question is whether this means that students who are good in academic areas such as Mathematics and English also have to be good at creative or physical subjects to be included in the register? Is it likely that children who display exceptional abilities in the creative and physical areas may be missed altogether from the register? The inherent problem here is that the 'gifted' and the 'talented' consist of 
two disjointed sets, which require separate sets of criteria for membership which makes the teachers' task of selection challenging. These problems suggest that the issue of terminology and the way we record students' gifts and talents needs to be reconsidered.

\section{General or domain specific giftedness}

A related problem, highlighted in the responses from teachers, is that $63 \%$ of primary schools do not use subject-specific criteria for identifying their gifted and talented children. As schools are organised to teach different subjects and as there is strong support for the existence of domain-specific intelligences (Gardner 1983; 1993; Van Tassel-Baska 1998), it would seem prudent for teachers to use subject-specific criteria for identifying gifted and talented students. This would also support subject-specific planning and provision. In Van Tassel-Baska's (2005a) conception of giftedness, giftedness becomes the manifestation of intelligence within specific domains at very high levels and conceptions that focus on domain-specific considerations hold the most promise for promoting talent development in individuals at all stages of development because of the capacity to make appropriate correspondence between aptitudes and interventions and between predispositions and interests. The view that ability is multi-dimensional and the fact that individuals vary considerably in their ability to function effectively in various domains adds support to this view. The author maintains that consideration must be given to the 'rubber band effect' of human potential and that the key is to provide the best opportunities to stretch an individual's potential flexibly in areas of best flexibility for learning. It seems that teachers' practices in our sample ignore the concept of domain -specific ability within their identification process.

\section{The gifted and talented register}

It also seems that there are problems associated with publicising the membership of the gifted and talented group; $53 \%$ of students do not know they are on the register and only $42 \%$ of parents were told their children were part of the gifted and talented cohort. This practice varied in different schools. This complicates the analysis of any consequences of labelling on motivation, self-identity and development of those who are on the gifted and talented register and those children who are left out. 


\section{Challenges for the teacher}

The identification of a cohort of children, consisting of 5 to $10 \%$ of each annual intake into a school, and placing them on a gifted and talented register has posed the greatest challenge to the teaching profession and to the schools involved since the introduction of the gifted and talented initiative in the UK. In their evaluation of the gifted and talented strand of the Excellence in Cities programme, Ofsted (2001) described identification issues as presenting the most concern for schools and Eyre (2001:1) maintains that although the gifted and talented programme has enjoyed a good deal of success in raising awareness of the need for enhanced curriculum provision, the creation of the cohort has been the most problematic part of the policy.

The first difficulty involves the terminology used. Although a small number of educational programmes for the gifted and talented have been in existence for many decades in the UK, there has been no precipitation of a universal acceptance of the semantics of the terminology. The range of social, economic and political perspectives may possibly ensure that a unified definition could never materialise. Significantly, Freeman (1998) uses the title 'Educating the Very Able' for her review of international research on gifted education which was commissioned by the Ofsted. In that report she throws some light on the nature of the complexity by stating that there are over 100 definitions to describe these pupils such as very able, high ability and the troublesome word gifted and that, whilst acknowledging that as almost all international researchers use the term gifted, it would be verging on the deviant to avoid using it. In a collaborative study, conducted by the first author of this paper (Radnor, Koshy and Taylor 2007), it was found that many teachers have philosophical difficulties aligning themselves to a policy which labels children as 'gifted and talented' and making special provision for them.

Historically, in the field of gifted education the question of terminology has always been under constant revision. In the 1950s the term gifted was used on the basis of the results of Intelligent Quotient tests carried out by Terman (1925) for the purpose of selecting pupils for specially designed educational programmes. Terman used a cut-off point of an IQ score of 140 for selection, although exceptions were made to select pupils down to a score of 135 (Feldhusen 2003). A broadening of the concept of ability and research in the last few decades has led to a revision of Terman's definition of giftedness based on IQ 
scores. Currently, there are continuing debates within the field of gifted education about the need to rethink the terminology (Borland 2005; Matthews and Folsom 2009). Dweck's (2009) research on the malleable nature of intelligence and the effect of the 'mindset' on the academic functioning, success and the learning power of the learner has challenged the view of 'giftedness' as fixed. Dweck's 'growth mindset' intervention has shown how it can enhance students' motivation and achievement compared with that of those who hold a 'fixed mindset' which leads them to avoid challenges, devalue effort and under-perform in the face of difficulty.

A review of recent research literature on the use of the words gifted and talented, offers some possible reasons for the unease felt by practicing teachers. We should take note of the cautionary words from two experts in the field of gifted education - Feldhusen and Jarwan (2001: 279) - that the use of the word gifted to identify and label children needs to be considered in the light of the best current theories of human aptitude, talent and abilities. The authors advise us against labelling children as gifted and to regard the process of identification as selecting children for programmes and services. They maintain that the labelling process leaves those children who are not selected to be viewed as ungifted whereas a good programme should help all pupils to identify their talents. The concepts of general giftedness, gifted child and gifted education, according to the authors, are no longer tenable in the light of emerging research and theory on human abilities. Within the British context, Ofsted (2001:15) found that not being selected as gifted and talented was seen by some pupils to be unfair and resulted in them being excluded from some activities. They were, as a result, described as demotivated.

\section{Considering the dilemma - are gifts and talents fixed or developing?}

Another area of discomfort may arise from the notion of gifted and talented being viewed as a fixed state. Recent literature (Sternberg 2000) supports the concept of giftedness as developing rather than developed expertise, a view also held by Dweck (2009). Sternberg maintains that this expertise is not an end-state, but a process of continual development He asserts that gifted individuals need to continually be developing the kinds of expertise that render them gifted and that if they do not, they stop being identified as gifted or become gifted has-beens. Further support for the developing nature of giftedness comes from Clarke (2001: 5) who challenges the concept of the genetically inherited, immutable 
view of intelligence as being no longer valid. Based on brain function research she declares:

"Intelligence must be considered dynamic just as the growth of the functions of the brain is dynamic with higher levels of intelligence actualized only when appropriate challenge is provided."

\section{Use of tests for the selection of gifted and talented children}

The predominant method of identification, used by the teachers in the sample, was based on national or school test results. $96 \%$ of the respondents said they used Key Stage 1 test results (test taken at the age of 7 ) to help to identify their gifted and talented children. 95\% of the teachers said that they also used additional tests (such as end-of-year tests from the government's Qualifications and Curriculum Authority (QCA)) as support. Many questions can be raised here. First, is it possible that teachers were using national tests which are part of the government's monitoring system for assessing performance of children in schools as a self-protection mechanism as they are aware of the complexity and the fallibility of the selection process? Is it possible that teachers have not been made aware that by over-reliance on test results they may exclude children with creative abilities, those with lack of motivation or disabilities, from membership of the 'gifted and talented' cohort. There is extensive research literature which has shown that traditional testing which assesses 'school house giftedness' (Renzulli 2005) often overlooks potential ability (Gardner 1993; Sternberg 2000; 2009). Van Tassel-Baska (2005a) highlights the fact that in the USA, where gifted education was established several decades ago,

giftedness is being mostly assessed using a combination of criteria which includes student portfolios, performance-based assessment, subject criteria and teacher assessment alongside tests. Van Tassel-Baska maintains that the increased use of non-traditional tools is a result of the dissatisfaction felt by educators that traditional assessments have not provided opportunities for students of 'colour, students of lower socioeconomic levels and students with uneven profiles'. A UK study has also documented that tests are not reliable indicators of giftedness in the case of students from socially disadvantaged backgrounds, where true ability may be submerged (Casey and Koshy 2002; 2006). Here it is also interesting to note that in our 1996 study (Thomas, Casey and Koshy, 1996) the use of traditional tests was not given much prominence for selection purposes, with $90 \%$ 
of teachers selecting teacher assessment as their main method of identifying gifted children.

\section{Early identification}

Responding to the question of identifying and including gifted and talented students to be included on a register, $83 \%$ of the schools in our sample said that their children were on the 'Gifted and Talented' register by the age of 6 . This aspect does cause concern for a number of reasons. First, although the intention of government policy is to provide special provision for the whole age range through the Young Gifted and Talented programmes (www.ygt.dcsf.gov.uk), we could not find any training programmes designed to support teachers of the younger age group. Secondly, an audit of the content of the conferences and courses on gifted and talented education between 2007 and 2009, carried out by the authors, revealed that most of them had ignored the topic of younger children. Also, the latest government White Paper (DCSF 2009) has completely left out Key Stage 1 (ages 57) children from the gifted and talented selection. So, the question is, on what basis and understanding are teachers identifying children as 'gifted and talented' before they are 6 years old?

Indeed, there are other questions that we need to ask. For example, could children who are not regarded as 'gifted and talented' by the age of 6 miss out on provision for the rest of their school years? Also, as there is a serious shortage of research into aspects of identification of younger children, what are teachers basing their decisions on? Existing research has shown that children's cognitive development is uneven and 'asynchronous' (Koshy 2001) in the first years of schooling which complicates the issue further. There has been some recent work, developed by the Scottish Network of Able Pupils (Sutherland, 2005; 2008), which explores the way teachers can impact learner beliefs about ability and suggest practical ways young children can be supported as they develop.

Most Early Years experts question whether it is necessary to label children at a young age and maintain that what is needed are stimulation, adult support and materials when the child is ready (Robinson 1993). High quality early childhood programmes have crucial benefits for children's development of their attitudes to learning and themselves as learners (Clarke 1997, Sylva 1994); so the emphasis should be on enriched provision rather than selection. Support for this view also comes from Clarke (1997) who points out 
that the brain is most malleable in the first five years; so early childhood is a critical period for facilitating children's development and, as Smutney, Veenker and Veenker (1987) recommend, instead of pumping information, what we need to do is to encourage younger children to develop their gifts and talents. Both Bloom (1985) and Gardner (1983) have guided our thinking that it is possible to see early signs of special aptitudes and giftedness in young children; as educators it is our duty is to nurture the young shoots of talent.

\section{An inclusive gifted and talented cohort}

One of the core elements of the UK government policy is 'narrowing the gap' between gifted children from lower socioeconomic backgrounds and those from middle class or wealthier backgrounds. This was one of the main themes of the Gifted and Talented initiative, from its origin in the Excellence in Cities (DfEE 1999) initiative, and the need for an inclusive register which represents the socio-economic characteristics of the school has always been stressed in all guidance documents. However, in our survey, only $24 \%$ of schools monitored their register for students' socio-economic background, and only $35 \%$ monitored for ethnicity. 19\% of schools did not monitor their registers for any vulnerable groups. Therefore, we can see that the issue of inclusion which is at the heart of government policy does not seem to be addressed fully at present in primary schools. The picture may be different in Secondary schools. A study by Campbell, et al (2007) highlighted that some ethnic groups were over-represented and some under-represented in the membership of the National Academy for Gifted and Talented Youth in the UK.

Issues of inclusion have implications. For example, the practical aim of the Widening Participation policy of the British government is to ensure that those with potential to follow a University education should have the opportunity to do so. As the gifted and talented cohorts in the schools are most likely to be the candidates to go to Universities and as issues of social mobility need to be addressed before children enter secondary schools, the issue of monitoring the gifted and talented cohorts in primary schools is important. The issue of underachievement and lack of aspirations amongst lower socio-economic groups has been highlighted in the last decade by various agencies in the UK (Office for Standards in Education 2001). Researchers (Casey and Koshy 2002) who have worked with high potential students in inner-cities for a number of years have shown that there is submerged talent in inner-city schools in the UK, and that this talent may be submerged but not eradicated by disadvantage. Support from the UK government to encourage 
inclusion include projects such as the REAL project (The Realising Equality and Achievement for Learners, 2010) which was set up in 2006 by the London Gifted and Talented and the Department for Children, Schools and Families to improve the overall quality of gifted and talented education for black and minority students and students learning English as an additional language. A support document, designed to support gifted and talented students with dual and multiple exceptionalities, has also been made available by the government (DCSF, 2008b).

Van Tassel-Baska (1998) maintains that one of the most neglected groups amongst gifted students is the bright student from a disadvantaged background and that the under representation of students from minority ethnic groups and lower social classes in enrichments programmes needs to be addressed. In England, Lucey and Reay (2002) found that students from middle classes tended to dominate the membership of gifted and talented cohorts of students created in response to the UK Government's (DfEE 1999) requirement that each secondary school (11-16 age group) select $10 \%$ of their intake and form a gifted and talented group.

Based on an evidence platform, the need for considering practices designed to improve academic opportunities of promising learners from lower income families is highlighted by Robinson, Bruce and Donna (2007). The authors list two possible barriers preventing these students from realising their potential: identification practices may not work in their favour and assumptions are made by educators, parents and policy makers about their potential for academic progress. The authors emphasise the need for programmes and services, that are of sufficient intensity and duration and which take into account family circumstances, to increase achievement and ultimately leverage these learners into a successful learning trajectory.

\section{Teachers' conceptions of giftedness}

One of the aims of our study was to gain insights about co-ordinators' beliefs and possible theoretical positioning. From the responses to many of the items in our survey, it is reasonable to assume that most teachers were hostile to the concept of selecting a group of children for membership of an exclusive 'gifted and talented' group and that they felt 
unease in the use of terminology. These teachers are likely to agree with Matthews and Folsom (2009) that a changed conceptualisation of giftedness and the adoption of a 'Mastery model' leading to a simple, practical, education-based definition of giftedness is necessary. The Mastery model defines Giftedness as exceptionally advanced subject specific ability at a particular point in time such that a student's learning needs cannot be well met without significant modification of the curriculum. Based on the responses to several of the questions in the survey, presented earlier in this paper, teachers are also likely to position themselves with the Borland view (2005) that the concept of the gifted child is a social construct of questionable validity and what we need to do is to focus on gifted education.

Realisation of the aim of analyzing teachers' responses according to their theoretical positioning has been challenging for a number of reasons. The different perspectives and conceptualisations of giftedness are not mutually exclusive. For example, teachers were using standardised tests, which are designed to assess specific subjects (in English, Mathematics and Science), to make a global assessment of giftedness. That does not mean that teachers did not subscribe to domain-specific giftedness. Similarly, teachers making decisions about whom to place on a 'gifted and talented' register using standardised tests cannot be interpreted to mean that they do not subscribe to a multidimensional view of giftedness which allows for creativity, flexibility and multiple perspectives. Only classroom observations of teaching and learning styles would throw light on this aspect. A follow-up study has been planned by the authors for this purpose.

However, open responses to questions suggested that there were teachers who subscribed to the view that 'gifts' are a natural endowment and are not so common, which is at odds with the requirement of a percentage population having to be selected and described as 'gifted and talented'. A range of conceptualisations of giftedness were revealed through the following responses:

"The terms, particularly gifted, are difficult. Gifted would mean outstanding, a prodigy! Surely 'more able' would be a better term for most of the children on our gifted register..." 
"Gifted means someone who is exceptional at something, a natural-inborn-gift. Very rare to see! Lots of more able, but gifted not so common. Talentedexceptionally brilliant at practical subjects like music, PE, singing etc."

"Gifted seems to suggest something that is from 'nature' rather than 'nurture', talents can be nurtured in all students."

"Giftedness is a hypothetical construct - viewed by many as something outstanding, a gift given to some. If someone has been given this gift, is it possible that that person may feel that he or she doesn't have to work hard to achieve? Is it also possible that the label of gifted bestowed on a person puts that person under a high level of pressure to live up to that label?"

For our follow-up study we intend to explore if and how teachers' beliefs and conceptions of giftedness translate into classroom practices.

\section{Limitations of the study}

Any investigation based on a sample is conducted in the hope that the generated picture is a good reflection of the larger reality from which it was selected. The main limitation of this study was the relatively low response-rate to the questionnaire although, as previously reported, other studies investigating the impact of new government policies in the UK have had similar levels of response-rate to that of the present study. Postal questionnaires are known for low response-rates. Edwards et al (2002) conducted a systematic review of studies which used postal questionnaires and found that the most effective way of increasing responses to postal questionnaires is to include a financial incentive. Although the authors considered this option, it was decided not to follow this route; but reminders with stamped envelopes were sent which are also said to increase responses (Dillman, 1991). On reflection, we feel that our questionnaire may have been relatively long as we were trying to explore several aspects of a very complex topic, which has not been the subject of inquiry so far in the UK.

The second limitation is that we do not have any information about how biased the sample of responses was. It is acknowledged that the high number of schools which did not 
respond to the questionnaire could have skewed the findings in different directions. For example, apathy relating to the policy may be greater than that indicated by the respondents. The non-respondents may not be engaging in the 'gifted and talented' initiative at all and had not wished to admit this fact. On the other hand, more positive support for the initiative may have gone unreported. Regardless of such potential limitations, the authors can report that the 'gifted and talented' policy has had some impact on the lives of many higher ability students. We also feel that the data obtained from this study has enabled us to gather a snapshot of what is happening, raise some pertinent issues and make some tentative conclusions. The analysis of the data and our deliberations should provide us-and possibly other readers-with starting points for further investigations.

\section{Concluding remarks}

By conducting the study reported in this paper, efforts have been made to gain insights into how teachers in primary schools in England and Wales were responding to the UK government's 'gifted and talented' policy which was launched in 1999; initially it covered secondary age groups (12-16) and then it extended to the whole 4-19 age range, five years later. Based on the responses from a national sample of primary school coordinators to an extensive list of items in a questionnaire, covering aspects of policy and practice we can summarise the following as our conclusions:

- Teachers are, on the whole, responding to the requirements of the policy - in terms of identification of children for membership of a 'gifted and talented' cohort, developing school policies and attending conferences and training sessions. They are making the best use of what is available - from documents, training, and school co-ordinators. Their practices seem to be based on pragmatic considerations. In this context, it is pertinent to refer to the study funded by the German government of 21 European states' educational provision for gifted students; it ranks the UK programme as one of the top three best providers. (Monks et al, 2005).

- A significant number of teachers are 'hostile' to the idea of using the label 'gifted and talented'. Many feel confused and find it difficult to interpret the two terms when selecting children for their 'gifted and talented' register. 
- Most teachers use standardised tests as a basis for the selection of their gifted and talented cohort. Two thirds of the schools identify their 'gifted and talented' by the time children are 6 - years old. There is also inconsistency in the policy of schools informing parents about their children's membership of the gifted and talented group.

- A third of the schools are not aware of the existence of the government's guidelines (IQS) which are designed to guide practical provision and monitor the effectiveness of the various strands of the policy. On the other hand, it should be highlighted that two thirds of the schools were cognisant of the existence of the IQS. But, the subject-specific criteria and support provided by the government's curriculum authority have not been used for making selection of children for the gifted and talented register.

- Teachers display a range of theoretical positions; these include difficulties with aligning themselves to the selection and labelling of a group as 'gifted and talented', a possible conflict about whether to conceive giftedness as 'all round' ability or 'domain-specific', and their strong reliance on the use of tests for identifying the gifted and talented.

- Issues of inclusion, were at the heart of the Labour government's policy, are ignored by many of the primary schools in the process of selection of their 'gifted and talented'

- Teachers conceptions of ability include giftedness being 'innate', 'natural born', 'being rare', 'outstanding... meaning a prodigy', 'exceptional at something', 'not so common' and 'something that is from nature' rather than nurture'. The implications of these beliefs and views on implementing government policy and on classroom practice may be significant.

To facilitate understanding of the summarisation above, it is useful to view the implementation of the policy as an input-output procedure. In this instance that procedure can be seen to be composed of 3 distinct parts. The first, input, consists of government policy, embodied in the documentation of requirements and guidance. The second part consists of teachers within the schools who are the processors of information, the third 
being the potential beneficiaries of the policy-higher ability children or those children who have the potential for high achievement.

The attitudes, beliefs and dispositions of the teachers-the processors-who have to process all the information provided to them in a plethora of government documents, are of fundamental importance to the successful implementation of the government's policy on gifted and talented education. Pertinent questions that need to be asked are:

- Are teachers, the processors in the 3 part-model, supported sufficiently to understand the complex nature of the concept of giftedness? Are they being provided opportunities to construct their own understanding of policy guidelines?

- Is the requirement to create a fixed percentage of children as 'gifted and talented' naive and ill conceived?

- Are the British teachers provided opportunities to engage in the on-going international discourse on the changing conceptions of giftedness which are moving away from the test - based, fixed view of human ability and potential to viewing it as flexible and developing in nature, where creativity and problem solving are encouraged? Is the UK policy lagging behind in our thinking about nurturing giftedness compared to other countries - USA, Australia and New Zealand, for example?

We propose two strategies as ways forward. First, there is a need for a greater level of longer, sustained professional development programmes to support practitioners in primary schools than there is at present. Support for practitioners on how to nurture younger children (4-7 year olds) should be part of that programme. Ultimately, the quality of what is offered to these pupils will, to a great extent, depend on the teachers' own level of understanding and expertise. There is a need for practitioners to construct their own understanding of issues, on the basis of authoritative research-based foundations. They need to create their own intelligible map of the different conceptions of ability and apply their awareness to their own practice. It is only by engaging in debates and discussion of different aspects of provision and how these relate to their own contexts that teachers can make a significant contribution to the challenging task of educating our most able pupils. 
The second strategy is to conduct more research on aspects of gifted and talented education within the British educational context. At present, there is only a very small body of research evidence available to practitioners on different models of provision and their effectiveness. One of the areas that needs urgent investigation is the effectiveness of various practices relating to identification and associated classroom provision. It is only right that our children are not subjected to models of provision which have not been tried and evaluated. One critical issue to be explored is what effect does the process of being identified as 'gifted and talented' have on children's social, emotional and educational lives.

Intellectual capital is important for any country; nurtured, it will benefit both the individual and the whole population. There is evidence that the government's 'gifted and talented' policy is making some contribution to making teachers aware of the existence of children with higher ability and the need to make provision for them. This has the potential to reduce the frustration felt by the kind of children highlighted by Her Majesty's Inspectorate decades ago (HMl 1978; 1979; 1992) and so change the landscape.

\section{References}

Bailey, R., G. Pearce, C. Winstanley, M. Sutherland, N. Stack and M. Dickenson. 2008. A systematic review of interventions aimed at improving the educational achievement of pupils identified as Gifted and Talented. In Research Evidence in Education Library. London: EPPI-Centre.

Bloom, B. 1985. Developing talent in young people. New York: Ballentine.

Borland, J.H. 2005. Gifted education without gifted children: The case for no conception of giftedness. In Conceptions of Giftedness ed. R. Sternberg and J. Davidson, 1-19. New York: Cambridge University Press.

Brody, L. and J. Stanley. 2005 Youths who reason exceptionally well mathematically and or verbally. In Conceptions of Giftedness ed. R. Sternberg and J. Davidson, 20-37. New York: Cambridge University Press.

Campbell, R.J., R. D. Mujis, J. G. A. Neelands, W. Robinson, D. Eyre, and R. Hewston. 2007. The social origins of students identified as gifted and talented in England: a geodemographic analysis. Oxford Review of Education 33 no.1: 103-120. 
Casey, R. and V. Koshy. 2002. Submerged talent and world class recognition. In Assessing Gifted and Talented Children. London: Qualifications and Curriculum Authority.

Casey, R. and V. Koshy. 2006. Submerged talent in inner cities-inclusion by intervention. In Including the Gifted and Talented: Making inclusion work for more gifted and able learners, ed C. M. M Smith, 87-101. London: Routledge.

Clarke, B. 1997. Growing up gifted: developing the potential of children at home and at school $5^{\text {th }}$ ed. Saddle River, NJ: Merrill.

Clarke, B. 2001. Some principles of brain research for challenging gifted learners. Gifted Education International, 16, no 1: 4-10.

Claxton, G. and S. Meadows. 2009. Brightening up: How children learn to be gifted. In The Routledge International Companion to Gifted Education, ed T. Balchin, B. Hymer and D. Matthews, 3-9. Oxon: Routledge.

Department for Children, Schools and Families. 2008a. Identifying Gifted and Talented learners - getting started. Department for Children Schools and Families publications.

Department for Children, Schools and Families. 2008b. Gifted and Talented Education: Helping to find and support children with dual or multiple exceptionalities. Department for Children Schools and Families publications.

Department for Children, Schools and Families. 2009. White paper: Your child, your schools, our future: building a $21^{\text {st }}$ century schools system. London: The Stationery Office

Department for Education and Employment. 1997. Excellence in Schools. London:

Department for Education and Employment.

Department for Education and Employment. 1998. DfEE News [Circular 413/98], April from Estelle Morris, Education Minister.

Department for Education and Employment. 1999. Excellence in Cities. London:

Department for Education and Employment.

Department for Education and Skills. 2006. National Quality Standards in Education. London: Department for Education and Skills.

Dillman, D. 1991. The design and administration of mail surveys. Annual Review of Sociology, 17: 225 -249.

Dracup, T. 2003. An outline of England's strategy for gifted and talented education, Gifted Education International, 17: 112-119. 
Dweck, C. 2009. Self -theories and lessons for giftedness: a reflective conversation. In The Routledge International Companion to Gifted Education, ed T. Balchin, B. Hymer and D. Matthews, 308-316. Oxon: Routledge.

Edwards, P, I. Roberts, M. Clarke, C. DiGuiseppi, R. Wentz, and I. Kwan. 2002. Increasing response rates to postal questionnaires: a systemic review. British Medical Journal, 24: 1183

Ericsson, K.A. 1996 The road to expert performance: Empirical evidence from the arts and sciences, sports and, games. Mahwah: NJ: Erlbaum.

Eyre, D. 2001. An effective primary school for the gifted. In Curriculum Provision for the Gifted and Talented in the primary school: English, Maths and ICT ed D. Eyre and L. McClure, 1-27 London: David Fulton.

Feldhusen, J. 2003. The nature of giftedness and talent and the pursuit of creative achievement and expertise. The Journal of the National Association of Gifted Children, 7, no. 1: 3-5.

Feldhusen, J. and F. Jarwan. 2001. Identification of gifted and talented youth for educational programs. In International Handbook of Giftedness and Talent, ed K. Heller, F.Monks, R. Sternberg, and R. Subotnik, 271-282. Oxford: Pergamon.

Freeman, J. 1998. Educating the very able. Current International Research. London: Ofsted.

Freeman, J. 2001. Gifted Children Grown Up. London: David Fulton.

Freeman, J. 2005. Permission to Be Gifted: How Conceptions of Giftedness Can Change Lives. In Conceptions of Giftedness ed R.J. Sternberg and J. E. Davidson, 80-97. Cambridge: Cambridge University press.

Gardner, H. 1983. Frames of mind. New York: Basic Books.

Gardner, H. 1993 Multiple intelligences. New York: Basic Books.

G\&T Update. 2010. Issue 72 March 2010

Geake, J and M. Gross. 2008. Teachers negative affect toward academically gifted students. Gifted Child Quarterly 52, no. 3: 217-231

Hartas, D., G. Lindsay, E. Arweck and S. Cullen. 2009. The nature and outcomes of PGCE Plus as a model for teacher professional development. Professional Development in Education 31 no.1: 101-118.

Her Majesty's Inspectorate. 1978. Primary education in England: A survey by HM inspections of schools. London: HMSO. 
Her Majesty's Inspectorate. 1979. Aspects of secondary education in England. London: HMSO.

Her Majesty's Inspectorate. 1992. Education observed: The education of very able pupils in maintained schools. London: HMSO.

House of Commons. 2010. The Gifted and Talented Programme: Oral and Written Evidence. Children, School and Families Select Committee, 1 Feb 2010. London: The Stationary Office.

Howe, M. 1999. The psychology of high abilities. New York: New York University Press.

Koshy, V. 2001. Teaching gifted children 4-7. London: David Fulton.

Koshy, V and R. Casey. 1997. Empowering the Teacher to Meet the Challenge of the Able Child. Early Child Development and Care, 130: 49-50.

Lucey, H. and D, Reay. 2002. Carrying the beacon of excellence: social class differentiation and anxiety at a time of transition. Journal of Education Policy, 17, no. 3: $321-336$

Maddern, K. 2009. Gifted and Talented face further reform - yet again. Times Education Supplement May 22, News

Matthews, D and C. Folsom. 2009. Making connections: cognition, emotion and a shifting paradigm. In The Routledge International Companion to Gifted Education, ed T. Balchin, B. Hymer and D. Matthews, 18-25. Oxon: Routledge.

Monks, F. J. and R. Pfluger. 2005. Gifted Education in 21 European Centuries: Inventory and Perspective. Nijmegen: University of Nijmegen.

Moon, T.R. and C.M. Brighton. 2008. Primary teachers' conceptions of giftedness. Journal for the Education of the Gifted, 31, no. 4: 447-480.

Neelands, J. G. A., S. Band, V. Freakley and G. Lindsay. 2006. Hidden Talents: A Review of State Supported Provision and Policy for Talented Pupils in England. Occasional Paper 2, Warwick: National Academy for Gifted and Talented Youth, University of Warwick.

Office for Standards in Education. 2001. Providing for gifted and talented pupils: An evaluation of Excellence in Cities and other grant- funded programmes. London: Office for Standards in Education.

Radnor, H, V. Koshy and A. Taylor. 2007. Gifts, talents and meritocracy. Journal of Education Policy, 22, no. 3: 283-299

REAL PROJECT http://teachertools.londongt.org/index.php?page=realProject. Accessed 21/5/2010. 
Renzulli, J. 2005. The three-ring conception of giftedness: A developmental model for creative productivity. In Conceptions of Giftedness ed R.J. Sternberg and J. E. Davidson, 246-279. Cambridge: Cambridge University press.

Robinson, A, M. Bruce. and L, Donna. 2007. Promising learners from low-income backgrounds. Best Practices in Gifted Education: An evidence based guide. Texas: Prufrock Press.

Robinson, N. 1993. Identifying and nurturing gifted, very young children. In International handbook of research and development of giftedness and talent ed K.A. Heller, F.J. Monks, and A.H. Passow, Oxford: Pergamon.

Robinson, W. and Campbell, J. 2010. Effective teaching in Gifted Education: Using a whole school approach. London: Routledge.

Robinson, W., R. J. Campbell. and L. Mazzoli 2006. Developing Expertise: School-based Case Studies. Occasional Paper 12, Warwick: National Academy for Gifted and Talented Youth, University of Warwick.

Sebba, J, N. Brown, S. Steward, M. Galton and M. James. 2007. An investigation of personalised learning: approaches used by schools. London: Department of Education and Skills. Research Report RR843.

Simonton. D.K. 2001. Totally made, not at all born. Review of the psychology of high abilities. M.J.A. Howe (Ed) Contemporary Psychology, 46, 176-179.

Smutney, J.F, K. Veenker. and S. Veenker. 1989. Your gifted child: how to recognize and develop the special talents in your child from birth to age seven. Ballantine: New York.

Sternberg, R. 2000. Giftedness as developing expertise. In International Handbook of Giftedness and Talent ed K. Heller, F. Monks, R. Sternberg, and R. Subotnik, 55-66 Oxford: Pergamon.

Sternberg, R. 2005. The WICS model of giftedness. In Conceptions of Giftedness ed R. Sternberg and J. Davidson, 327-342. New York: Cambridge University Press.

Sternberg, R. 2009. Wisdom, intelligence, creativity synthesized: a model of giftedness. In The Routledge International Companion to Gifted Education ed T. Balchin, B. Hymer, and D. Matthews, 255-264. Oxon: Routledge.

Sutherland, M. 2005. Gifted and Talented in the Early Years: Practical Activities for Children aged 3-5. London: Sage

Sutherland, M. 2008. Developing the Gifted and Talented Young Learner. London: Sage Sylva, K. 1994. School influences of children's development. Journal of Child Psychology and Psychiatry and Related Disciplines, 35, no. 1: 135-170 
Terman, L.M. 1925. Genetic studies of genius: Vol. 1, Mental and physical traits of a thousand gifted children. Stanford: Stanford University Press.

Thomas, L, R. Casey and V. Koshy. 1996. The education of able and exceptionally able children in England and Wales. Paper presented at the American Educational Research Association conference. April, New York, United States of America.

Van Tassel-Baska, J. 1998. The disadvantaged gifted. In Excellence in educating gifted and talented learners ed Van Tassel-Baska. J, 309-334. Colorado: Love Publishing Company.

Van Tassel-Baska, J. 2005a. Domain-specific giftedness: Applications in school and life. In Conceptions of Giftedness ed R. Sternberg and J. Davidson, 358-376. New York: Cambridge University Press.

Van Tassel-Baska, J. 2005b. Challenges and possibilities for serving gifted learners in the regular classroom. Theory into Practice, 44, no. 3: 211-217.

White, J. 2006. Education, Intelligence and Destiny: The Ideological Roots of Intelligence Testing. Abingdon: Routledge.

Westminster Institute of Education. Various practical and research papers on Gifted and Talented Education. Available from http://www.brookes.ac.uk/schools/education/rescon/cpdgifted/wie-research.html. Accessed 19/05/10

Young Gifted and Talented www.ygt.dcsf.gov.uk Accessed 13/10/09. 